Litinfinite Journal

ISSN: 2582-0400 [Online]

CODEN: LITIBR

Vol-2, Issue-1 ( $2^{\text {nd }}$ July, 2020)

Page No: 22-29

DOI: 10.47365/litinfinite.2.1.2020.22-29

Section: Article

\title{
From Epic Characters to a Movie Transformation: Tracing the Journey of Beowulf from Old English Poetry to Contemporary Motion Picture
}

\author{
Trishita Gautam ${ }^{1}$ \\ High School Teacher, Department of English \\ Jyotirmoy Public School \\ Kolkata, West Bengal, India \\ Mail I.d.: trishita34@gmail.com \\ Piyush Kumar Banerjee ${ }^{2}$ \\ Postgraduate Student, \\ University of Haifa, Israel \\ Erasmus+ study abroad scholarship recipient \\ Mail I.d.: piyushhunter23@gmail.com
}

\begin{abstract}
:
Beowulf, the tale of a celebrated hero and slayer of monsters, is the one of the finest and oldest epic poems of English literature. This poem was finally written down by an unknown poet after being passed on orally from one generation to another for many years. Beowulf has been translated from Old English to contemporary English by many scholars and has also been an inspiration for numerous films and games. Beowulf gives vivid descriptions of ancient Germanic people, an era of heroworshipping, supernatural beliefs and pagan rituals. It offers a re-living of the centuries-long phase of transformation of Europe. In this magnificent tale of war between 'the good and the bad'; the human and the monster; the hero and the villain; the saviour and the killer and the stronger and the strongest, there are several characters which stand out. Sturla Gunnarsson's Grendel and Beowulf (2005) and Robert Zemeckis' Beowulf (2007) are well-directed movies based on this famous epic. These movies borrow the central idea and characters from the epic while at the same time, also open broader doorways to view and interpret the text through variegated lens. This paper aims to compare and contrast the portrayal of the four important characters of the epic with these two movies. This paper will try to explore the inconsistencies in the depiction of these major characters of this poem in the contemporary films.
\end{abstract}

Keywords- Beowulf, Hero, Monster, Mother, Film

'Epic poetry has shaped the way that we perceive our universe. We've used these epics to justify ourselves...'

'Oral traditional epic is not merely entertainment, as it tends to become in the course of time and social change, but has a serious function in society.'

\footnotetext{
1 "Looking at Epic Poetry Through 21st-Century Eyes - The New York Times." The New York Times - Breaking News, World News \& Multimedia. N.p., n.d. Web. 7 Jan. 2020.

<https://www.nytimes.com/2020/07/23/books/epic-poem-boewulf-aeneid-faerie-queene.html> (accessed

February 15, 2020)
} 
CODEN: LITIBR

Vol-2, Issue-1 ( $2^{\text {nd }}$ July, 2020)

Page No: 22-29

DOI: 10.47365/litinfinite.2.1.2020.22-29

Section: Article

Beowulf emerges from a general background of oral poetry that puts the reader in touch with traditional modes of thinking and of perceiving the world. ${ }^{3}$ The epic retains its archaic essence and bears nostalgia of the old English society, with its heroic tales of battles and victories that often flout logic. It also acknowledges the fundamental problems of both the community and the individual and how to meet and accept them if they cannot be resolved. The characters in the epic are multifaceted and every reading of the epic renders new meanings to the events. It continues to be 'culturally productive' 4 even today, as the interest in popular archaic-heroic fantasy narratives has been rekindled by the Lord of the Rings franchise..$^{5}$ All these contribute to Beowulf's vast appeal till present times and many adaptations which have been made based on the story.

This paper proceeds to focus on two films, namely Beowulf \& Grendel (2005) and Beowulf (2007), with the view to compare them to the epic and analyse how they coincide with or deviate from the epic. The paper will also explore the portrayal of the four major characters namely, Beowulf, Grendel, Hrothgar and Grendel's mother in the films.

\section{Beowulf- the journey of an epic hero}

"In his far-off home Beowulf, Higlac's

Follower and the strongest of the Geats-greater

And stronger than anyone anywhere in this world-"6

In the epic, the central character of Beowulf has been portrayed in two different phases of his life- divided by an interval of fifty years. In the first phase of his life, Beowulf is seen as a brave warrior without fear, of any man or monster, in his heart. This aspect of his character remains unchanged in both the original poem and the movies. What remains unexplored is the driving force behind Beowulf's lust for adventure- whether it is his intrinsic urge to help the needy or the hunger for fame and glory in both the epic and the movies. His hunger for fame accompanied by pride stays a primary characteristic of his character throughout the story-telling. An aspect that has been added to his character is his amorous nature. In Gunnarsson's movie, the witch Selma entices Beowulf, while Zemeckis takes Beowulf's amorous adventures a notch higher and establishes his relationships with multiple women characters. Also, in the 2007 adaptation of the epic, Beowulf is not only hungry for fame but

\footnotetext{
${ }^{2}$ Beowulf and Oral Epic Tradition." CHS. N.p., n.d. Web. 20 June 2020.

<https://chs.harvard.edu/CHS/article/display/6275.4-beowulf-and-oral-epic-tradition> (accessed January 25, 2020)

${ }^{3}$ Sorrell, Paul. "Oral Poetry and the World of Beowulf," Oral Tradition. 7(1), 1992, 29

${ }^{4}$ Coles, Jane, and Theo Bryer. "Reading as enactment: transforming Beowulf through drama, film and computer game." English in Education 52.1 (2018): 54-66.

5 "(DOC) "Beowulf" and the Influence of Old English on J.R.R. Tolkien's The Lord of the Rings | Hugo J. Morin Academia.edu." Academia.edu - Share Research. N.p., n.d. Web. 8 May 2020. $<$ https://www.academia.edu/1567195/Beowulf and the Influence of Old English on J.R.R. Tolkien s The Lord of the Rings> (accessed January 21, 2020)

${ }^{6}$ quoted from Raffel, Burton. Beowulf. New York: New American Library, 1963, 17
} 
Litinfinite Journal

ISSN: 2582-0400 [Online]

CODEN: LITIBR

Vol-2, Issue-1 ( $2^{\text {nd }}$ July, 2020)

Page No: 22-29

DOI: 10.47365/litinfinite.2.1.2020.22-29

Section: Article

also greedy for power. His bargain with Grendel's mother would act as the catalyst behind his doom.

\section{Hrothgar - Is he the Ideal King?}

"Then Hrothgar, taking the throne, led

The Danes to such glory that comrades and kinsmen

Swore by his sword..."7

This is how the poet introduces the reader to the just and generous King of the Danes. In Beowulf, what marks Hrothgar different from Kings before his time, is the erection of his great mead-hall, Herot. He built it with the vision of giving his subjects the gift of joy and light, through celebration, where 'he would share out among young and old all God has given him...,

Hrothgar is loved and revered by his people and he 'had power everywhere'. . He too had undying concern for his subjects and Grendel's attack on his men had made him griefstricken. Sturla Gunnarson's Hrothgar too is not scared of shedding tears. The death of his subjects had truly devastated him and he was ready to perform every task to save his kingdom from the grip of the monster-he converts himself into Christianity and undergoes Baptism. This may prove two things- he was either desperate to save his subjects or too driven to retain his reputation as the great king.

Gunnarson's Beowulf \& Grendel provides an understanding of Hrothgar's characteralthough he is not entirely free of pride and recklessness, he does possess some benevolence in his heart, which is depicted in the initial sequences of the 2005 movie, where Hrothgar kills Grendel's father but spares young Grendel- 'weakness stopped my sword', ${ }^{10}$ said he. Despite this, he considers Grendel just a monster with no purpose or sentiments; he thrives on the denial of having murdered his father.

The 2007 adaptation of the epic, directed by Robert Zemeckis, written by Neil Gaiman and Roger Avary, makes further additions to the stout-hearted character of Hrothgar; the opening scene shows Hrothgar immersed in the intoxication of the mead that his mead-hall Herot was popular for. In his words, the hall had been built for 'celebration and fornication'11 although he hadn't been able to establish a love-laced relationship with his wife. This cinema also gives us a glimpse of the luxurious king's bravery, when he stands up against the gigantic Grendel, snatching a sword from one of his men, even in his drunken stupor. Yet, Zemeckis's Hrothgar stands apart in the way he condemns passive submission to divine powers- 'No, the

\footnotetext{
${ }^{7}$ Raffel, Burton. Beowulf. New York: New American Library, 1963, 110

${ }^{8}$ Chickering, Howell D. Beowulf: A Dual-language Edition. Anchor Canada, 2006

${ }^{9}$ Ibid

10 itachi. "Beowulf \& Grendel Espagnol." YouTube, uploaded by itachi, 14 Apr. 2015, $<$ www.youtube.com/watch?v=GBjFAVah-Vo\&t=299s. $>$ (accessed January 23, 2020)

${ }^{11}$ TheFantasyCentral. "Beowulf (2007)." YouTube, uploaded by TheFantasyCentral, 4 Feb. 2011, $<$ www.youtube.com/watch?v=DaShOr5AeKA\&list=PLTLNwZ6BJw3E4-KIQpvUavf--snQn4Qxx.> (accessed February 14, 2020)
} 
Litinfinite Journal

ISSN: 2582-0400 [Online]

CODEN: LITIBR

Vol-2, Issue-1 ( $2^{\text {nd }}$ July, 2020)

Page No: 22-29

DOI: 10.47365/litinfinite.2.1.2020.22-29

Section: Article

gods will do nothing for us that we will not do for ourselves. What we need is a hero' ${ }^{12}$-he confidently says. Nevertheless, the cinema also shows the fragile and vulnerable side of Hrothgar, exposed only to the audience- in his youth he had given in to the temptations offered by the appealing form of Grendel's mother and Grendel was the outcome of their secret union. Perhaps the lion-hearted monarch wasn't so strong-willed after all and it may be inferred that it was this weakness of his that caused the Danes their doom. However, His unforeseen death, fit to be called an act of suicide, makes us question whether the generous king, with his strengths and weaknesses, deserved such a lowly death.

\section{Grendel's Mother- The 'un-named' monster}

The nameless monster after whom the twelfth chapter of the epic has been named carries on the gory legacy of her deceased son, 'and in her dripping claws carries off one-man'. ${ }^{13}$ The absence of a name reflects the apparent fact that she owes her existence in the epic to her son Grendel and his death; she is driven by vengeance. Her identity bearing the 'Mother' is also indicative of the fact that her act of brutality against Hrothgar's closest friend is not merely obtuse savagery. She attacks Herot 'in grief of her son'14, and 'she does so with notable restraint, taking a life for a life, 15 , says Jacob Howland in his "Beowulf" \& history. She has been endowed with the human(e) quality of emotions despite being a monster. Although a female, she gave the mighty Beowulf a stiff fight- 'no sword could slice her evil Skin'. ${ }^{16}$ It was the woven metal armour-suit on his chest that saved his life against her. Her death was finally caused by a magical sword that Beowulf found, hanging on the wall of the monsters' lair.

The treatment of her character in the 2005 cinema Beowulf \& Grendel is equivalent to that in the epic. As in the epic, Grendel's Mother's actions in the movie do not go beyond avenging her son's death. She embodies the same emotions as in the original plot and she howls in despair.

In the 2007 Beowulf, however, director Robert Zemeckis has taken a very distinct and discrete course in his treatment of Grendel's Mother- as a shape-shifting, promiscuous enchantress. Here, she has been depicted as being involved in an affair with Hrothgar and consequently conceiving Grendel as her son. The cinema uses the beautiful, voluptuous, beguiling female form of the loathsome sorceress, propelled by greed, stripped off of kindness, using deception to flatter their keen interests in destruction.

\footnotetext{
12 Ibid

${ }^{13}$ Raffel, Burton. Beowulf. New York: New American Library, 1963, 29

14 Ibid

15 " "Beowulf" \& History by Jacob Howland | The New Criterion." The New Criterion - A Monthly Review of the Arts \& Intellectual Life. N.p., n.d. Web. 19 June 2020, 25

$<$ https://newcriterion.com/issues/2020/6/beowulf-history> (accessed February 16, 2020)

${ }^{16}$ Raffel, Burton. Beowulf. New York: New American Library, 1963, 31
} 
CODEN: LITIBR

Vol-2, Issue-1 ( $2^{\text {nd }}$ July, 2020)

Page No: 22-29

DOI: 10.47365/litinfinite.2.1.2020.22-29

Section: Article

Zemeckis uses the face of the 2009 'Voted World's Most Beautiful Woman'17 to play the role of the monster's mother, who is a Water Demon. However, her rendezvous with Beowulf isn't one that ended in bloodshed; he is instead seduced and persuaded into believing her promise to make him the King in exchange for the golden drinking horn (a gift from Hrothgar) and a son to replace Grendel. Zemeckis here portrays a woman for whom her son's death is mournful but her paramount objective is to preserve her bloodline, through seduction and bargains. The concluding sequences of the cinema, that show Grendel's mother appearing before the ship carrying Beowulf's burning corpse and gives a final kiss before it sinks into the sea, followed by her attempts at seducing Beowulf's dear friend and lieutenant Wiglaf, remind us of the Sirens of Greek Mythology, who were known for luring sailors to their doom, with their enchanting forms and music.

The Water Demon, who succeeds in seducing both Hrothgar and Beowulf and acquires wealth and motherhood as she desires, brings to light the frailty and weakness in the worshipped and celebrated characters of the just King and the Undefeated hero. The glorified figure of Hrothgar or the invincible frame of Beowulf is not immune to temptations of avarice or fame.

Zemeckis's Grendel's Mother somewhat echoes of Shakespeare's Three Witches that appear in Macbeth. Just as the Weird Sisters make use of persuasion and deception to lure Macbeth to his eventual doom, by fulfilling their trivial promises, Grendel's Mother too leads the men to their ruin, in the cinema. She acts as a powerful feminine force, capable of rendering masculinity impotent and futile, as both Hrothgar and Beowulf had been rendered sterile after their lascivious involvement with her. Simultaneously, she also assumes a position much more significant than her son Grendel, rises above the identity of just a maternal figure, as in the epic. Her tales of causing ruin precedes Grendel's birth and stretches past his death.

\section{Grendel - Just a vile monster or...?}

The first chapter of the epic is titled The Monster Grendel and the monster has been introduced as 'growled in pain' ${ }^{18}$ due to the celebratory noise that Hrothgar's subjects created in Herot. This monstrous creature of nature has been soon described most viciously, as being 'conceived by a pair of those monsters born of Cain' ${ }^{19}$. In most parts of the epic, he carries out his reign of terror and blood, slaughtering Danes in their sleep, until Herot stood empty and silent for twelve winters. Although he never dared to touch Hrothgar's Throne, which was believed to have been protected by God, the 'mankind's enemy' ${ }^{20}$ continued satiating his thirst for blood, by killing as many Danes as he could at nightfall.

\footnotetext{
17 "Angelina Jolie Is the Most Beautiful Woman in the World." Vanity Fair. N.p., n.d. Web. 22 June. 2020. <https://www.vanityfair.com/news/2009/04/angelina-jolie-is-the-most-beautiful-woman-in-the-world> (accessed January 28, 2020)

${ }^{18}$ Raffel, Burton. Beowulf. New York: New American Library, 1963, 14

19 Ibid

${ }^{20}$ Ibid, 17
} 
Beowulf's victory against Grendel and Grendel's miserable death shows that the anonymous poet was not inclined at rendering any depth to the character of the rogue monster, the is only instrumental in bringing to light the pre-eminent gallantry of the epic hero. Nonetheless, Jacob Howland in "Beowulf" \& History writes- 'Beowulf and Grendel are cousins, branches split off from the same trunk by the primal eldest sin. The family resemblance is strong', ${ }^{21}$ a resemblance deduced from their inhuman strength and their bloody involvements.

In 2007's Beowulf, Robert Zemeckis does not drift too far in his portrayal of Beowulf; he is nothing beyond a gruesome, malformed troll-like monster, possessing horrific strength, with the only weakness of hypersensitive hearing. Although his presence in the cinema is brief, it is appalling and vile. However, the final glimpses of him in his den, when he painfully submits to death, are rather paltry and evoke pity.

The 'vicious monster' 22 on a mission to ravage the Danes, has been made one of the titular characters in Sturla Gunnarsson's Grendel \& Beowulf, alongside the hero Beowulf. The movie, like in the epic, does not begin in medias res $^{23}$, in order to offer a complete insight into the process of Grendel becoming the murderous monster. Young Grendel is introduced in the movie as a witness to the killing of his Troll father by the Danes, led by Hrothgar. Although Hrothgar spares his life, he spends his days nurturing the plan for avenging his father's murder, due to merely crossing paths with the Danes. The 'monster' is seen mourning for his father, expressing his agony through deafening howls. He begins executing his plans for vengeance when he grows big and strong, but he proves he is not just a bloodthirsty monster that kills for pleasure. With the arrival of Beowulf to Denmark, it is revealed that only able-bodied soldiers fall prey to Grendel's vicious claws in the dark of the night. When Beowulf follows Grendel into the bewilderment, with the hope to fight him, the gibberish-uttering monster refuses to fight back as he was not a Dane and had done him no wrong. This instance renders the line separating humans from monsters obscure and Grendel's character evokes pity and sympathy, instead of abhorrence. Eventually, he also proves to be a creature possessing libido; he fathers a child with a witch named Selma, a character who appears only in Gunnarsson's adaptation of the epic. Gunnarsson carefully creates a monster with a past that shapes him into the grinder that he had become. This character raises doubts about the societal notions of the 'monster' and the 'human'.

\footnotetext{
21 "“Beowulf" \& History by Jacob Howland | The New Criterion." The New Criterion - A Monthly Review of the Arts \& Intellectual Life. N.p., n.d. Web. 19 June 2020, 25 $<$ https://newcriterion.com/issues/2020/6/beowulf-history> (accessed February 19, 2020)

22 "In Beowulf, is Grendel an Actual Monster, a Wicked Man, or a Symbol of Immorality?" ENotes. N.p., n.d. Web. 25 May 2020.

<https://www.enotes.com/homework-help/beowulf-grendel-an-actual-monster-wicked-man-1073168> (accessed February 25, 2020)

${ }^{23}$ In medias res (Latin: "in the midst of things") is the practice of beginning an epic or other narrative without any introduction, in or into the middle of a plot.
} 
Beowulf is still considered the 'greatest of the surviving works of ancient English poetic art. ${ }^{24}$ It is a timeless and classic representation of themes like good vs. evil, strength and skill, courage, honour et al. Although the movies do uphold these themes with clarity, they do not give merit to the epic in the manner in which the characters have been portrayed in the movies. There are also significant altercations in the story. Despite promising attempts, both the movies fall short in portraying the same vigour and intensity that the original narrative embodies. As Richmond Lattimore has stated in his On Classical and English Poetry, 'It is the original poets, not the derivative, who best represent their age... ${ }^{25}$ The movies have, to some extent, striped the major characters of their honour and principles, in an attempt to endow them with additional human qualities. In the vintage story of Beowulf, Beowulf embodies the true characteristics of an epic hero. He is selfless and empathetic and his fidelity to the heroic code of honour made him into the hero that he is known as today. The movies do not depict Beowulf in the same heroic manner; he is more proud, avaricious, arrogant and sexual. The movies also take away the prestige and worth that Hrothgar's character deserves. They do not succeed in conveying the true themes of the classic story meritoriously. Following the oral traditional character, the medieval English epic not only provides a 'cohesive vision for society' ${ }^{26}$, but also creates opportunities for every generation of readers to envision it anew. Consequently, the 'villains' (Grendel and Grendel's Mother) in the films have been given 'persuasive emotional back stories' 27 and this has unfurled newer avenues for further imagination and elucidation.

\section{Works cited}

i. $\quad$ "(DOC) "Beowulf" and the Influence of Old English on J.R.R. Tolkien's The Lord of the Rings | Hugo J. Morin - Academia.edu." Academia.edu - Share Research. N.p., n.d. Web. 8 May 2020.

<https://www.academia.edu/1567195/Beowulf_and_the_Influence_of_Old_English_o n J.R.R. Tolkien $s$ The Lord of the Rings $>$

ii. $\quad$ "Beowulf" \& History by Jacob Howland | The New Criterion." The New Criterion A Monthly Review of the Arts \& Intellectual Life. N.p., n.d. Web. 19 June 2020. $<$ https://newcriterion.com/issues/2020/6/beowulf-history $>$

\footnotetext{
${ }^{24}$ Gilsdorf, Ethan. "J.R.R. Tolkien's Translation of 'Beowulf' Is Published - The New York Times." The New York Times - Breaking News, World News \& Multimedia. N.p., n.d. Web. 12 Jan. 2020.

<https://www.nytimes.com/2014/05/19/books/irr-tolkiens-translation-of-beowulf-is-published.html> (accessed February 22, 2020)

${ }^{25}$ Lattimore, Richmond. "On Classical and English Poetry." Phoenix 6.3 (1952): 84.

26 "Looking at Epic Poetry Through 21st-Century Eyes - The New York Times." The New York Times - Breaking News, World News \& Multimedia. N.p., n.d. Web. 7 Jan. 2020.

<https://www.nytimes.com/2020/07/23/books/epic-poem-boewulf-aeneid-faerie-queene.html> (accessed January 14,2020$)$

${ }^{27}$ Ibid
} 
iii. "Angelina Jolie Is the Most Beautiful Woman in the World." Vanity Fair. N.p., n.d. Web. 22 June. 2020. <https://www.vanityfair.com/news/2009/04/angelinajolie-is-the-most-beautiful-woman-in-the-world $>$

iv. $\quad$ "In Beowulf, is Grendel an Actual Monster, a Wicked Man, or a Symbol of Immorality?" ENotes. N.p., n.d. Web. 25 May 2020. $<$ https://www.enotes.com/homework-help/beowulf-grendel-an-actual-monsterwicked-man-1073168>

v. $\quad$ "J.R.R. Tolkien's Translation of 'Beowulf' Is Published - The New York Times." The New York Times - Breaking News, World News \& Multimedia. N.p., n.d. Web. 5 July. 2020. <https://www.nytimes.com/2014/05/19/books/jrr-tolkiens-translation-ofbeowulf-is-published.html>

vi. $\quad$ "Looking at Epic Poetry Through 21st-Century Eyes - The New York Times." The New York Times - Breaking News, World News \& Multimedia. N.p., n.d. Web. 7 Jan. 2020. <https://www.nytimes.com/2020/07/23/books/epic-poem-boewulfaeneid-faerie-queene.html $>$

vii. $\quad$ Beowulf and Oral Epic Tradition." CHS. N.p., n.d. Web. 20 June 2020. <https://chs.harvard.edu/CHS/article/display/6275.4-beowulf-and-oral-epic-tradition>

viii. $\quad$ Chickering, Howell D. Beowulf: A Dual-language Edition. Anchor Canada, 2006. Print.

ix. Coles, Jane, and Theo Bryer. "Reading as enactment: transforming Beowulf through drama, film and computer game." English in Education 52.1 (2018): 54-66. Print.

x. Gilsdorf, Ethan. "J.R.R. Tolkien's Translation of 'Beowulf' Is Published - The New York Times." The New York Times - Breaking News, World News \& Multimedia. N.p., n.d. Web. 12 Jan. 2020. <https://www.nytimes.com/2014/05/19/books/jrrtolkiens-translation-of-beowulf-is-published.html>

xi. $\quad$ itachi. "Beowulf \& Grendel Espagnol." YouTube, uploaded by itachi, 14 Apr. 2015, <www.youtube.com/watch?v=GBjFAVah-Vo\&t=299s.>

xii. $\quad$ Lattimore, Richmond. "On Classical and English Poetry." Phoenix 6.3 (1952): 84. Print.

xiii. Raffel, Burton. Beowulf. New York: New American Library, 1963. Print.

xiv. $\quad$ Sorrell, Paul. "Oral Poetry and the World of Beowulf," Oral Tradition. 7(1), 1992. Print.

xv. TheFantasyCentral. "Beowulf (2007)." YouTube, uploaded by TheFantasyCentral, 4 Feb. 2011, <www.youtube.com/watch?v=DaShOr5AeKA\&list=PLTLNwZ6BJw3E4KIQpvUavf--snQn4Qxx.> 